Article

\title{
High Cell Density Conversion of Hydrolysed Waste Cooking Oil Fatty Acids Into Medium Chain Length Polyhydroxyalkanoate Using Pseudomonas putida KT2440
}

\author{
Carolina Ruiz ${ }^{1}$, Shane T. Kenny ${ }^{2}$, Ramesh Babu $\mathrm{P}^{3}$, Meg Walsh $^{2}$, Tanja Narancic ${ }^{1,4}(\mathbb{D}$ and \\ Kevin E. O'Connor ${ }^{1,4, *}$ \\ 1 UCD Earth Institute and School of Biomolecular and Biomedical Science, University College Dublin, \\ Belfield, D04 N2E5, Dublin 4, Ireland; carolina.ruiz@ucdconnect.ie (C.R.); tanja.narancic@ucd.ie (T.N.) \\ 2 Bioplastech Ltd., Nova UCD, Belfield Innovation Park, University College Dublin, Belfield, D04 V2P1, \\ Dublin 4, Ireland; skenny@bioplastech.eu (S.T.K.); meg.walsh@ucdconnect.ie (M.W.) \\ 3 AMBER Centre, CRANN Institute, School of Physics, Trinity College Dublin, Dublin 2, Ireland; \\ BABUP@tcd.ie \\ 4 BEACON-Bioeconomy Research Centre, University College Dublin, D04 N2E5, Belfield, Dublin 4, Ireland \\ * Correspondence: kevin.oconnor@ucd.ie; Tel.: +353-1-716-2198; Fax: +353-1-716-1183
}

Received: 30 April 2019; Accepted: 20 May 2019; Published: 21 May 2019

check for updates

\begin{abstract}
Waste cooking oil (WCO) is a major pollutant, primarily managed through incineration. The high cell density bioprocess developed here allows for better use of this valuable resource since it allows the conversion of WCO into biodegradable polymer polyhydroxyalkanoate (PHA). WCO was chemically hydrolysed to give rise to a mixture of fatty acids identical to the fatty acid composition of waste cooking oil. A feed strategy was developed to delay the stationary phase, and therefore achieve higher final biomass and biopolymer (PHA) productivity. In fed batch (pulse feeding) experiments Pseudomonas putida KT2440 achieved a PHA titre of $58 \mathrm{~g} / 1$ (36.4\% of CDW as PHA), a PHA volumetric productivity of $1.93 \mathrm{~g} / \mathrm{l} / \mathrm{h}$, a cell density of $159.4 \mathrm{~g} / \mathrm{l}$, and a biomass yield of $0.76 \mathrm{~g} / \mathrm{g}$ with hydrolysed waste cooking oil fatty acids (HWCOFA) as the sole substrate. This is up to 33-fold higher PHA productivity compared to previous reports using saponified palm oil. The polymer (PHA) was sticky and amorphous, most likely due to the long chain monomers acting as internal plasticisers. High cell density cultivation is essential for the majority of industrial processes, and this bioprocess represents an excellent basis for the industrial conversion of WCO into PHA.
\end{abstract}

Keywords: biopolymers; medium chain length polyhydroxyalkanoates (PHA); hydrolysed waste cooking oil; Pseudomonas putida KT2440; biocatalysis; bioprocess

\section{Introduction}

Petrochemical based plastics have been used in a variety of applications for more than seventy years and have replaced materials like glass and metal due to their high performance, low price, versatility, and durability [1,2]. The worldwide annual production of plastics was 335 million tonnes in 2016, and its production is expected to triple by 2050 [2]. Many of the uses of plastics are short term, and consequently these materials become waste within a short period of time after manufacture and use. The vast majority of petrochemical based plastics are not biologically degraded [3]. Plastic recovery and recycling rates are low [4], and thus millions of tonnes of plastics end up in landfills and in the environment [5-8]. Given the environmental damage caused by non-degradable plastics, there is an urgent need for solutions. Biodegradable plastics can be part of the plethora of solutions to address 
a complex global challenge. A critical challenge to providing biodegradable plastic solutions is the development of robust processes for biodegradable plastic production.

It is not just the end-of-life of plastics that is a concern for society, but also the origin of the starting materials. Materials of bio-based origin are being sought, as the origins of the current non degradable polymers are finite (fossil based) and depleting $[9,10]$. Biobased polymers can be produced from renewable resources such as corn dextrose, and many studies are investigating so called second generation (lignocellulose) sources [11-13]. Wastes, such as waste cooking oil, are also potentially interesting starting materials, but no studies have investigated this substrate for high cell density and high PHA productivity.

Polyhydroxyalkanoates (PHAs) are water-insoluble energy storage microbial polyester synthesized by many Gram-positive and Gram-negative bacteria when exposed to a surplus of carbon and generally a limitation of a vital inorganic nutrient $(\mathrm{N}, \mathrm{P}, \mathrm{S}, \mathrm{or} \mathrm{Mg})$ [1]. PHAs vary in the composition of the monomer side chain and hydroxyl position, which affects their material properties [14]. The monomer composition, and thus physical properties of PHA, can be tailored by co-feeding different carbon sources in fermentation cultivation systems [15-17]. For example, incorporation of monomers with unsaturated side chains in PHA will increase the melting temperature and decrease the glass transition temperature of the polymer [18]. Furthermore, these unsaturated bonds could be exploited for chemical or enzymatic modifications $[19,20]$ that can render PHAs water soluble or allow their coupling with functional molecules, and therefore broaden their application potential.

High production costs, compared to the traditional petrol-based plastics, remain the major challenge for polyhydroxyalkanoates entry into the plastics market. The use of inexpensive carbon sources, such as waste products, and a highly productive fermentation process could help to overcome the production costs [21-24].

Waste cooking oil (WCO) is a major waste from human food processing and preparation with over 29 million tonnes produced annually around the globe [25]. As WCO contains high levels of fatty acids, it might be suitable substrates for PHA production. It has been widely reported that fatty acids are excellent substrates for PHA accumulation by Pseudomonas strains with a PHA composition related to the chain length of the fatty acid supplied [26-30].

Currently, there are a limited number of studies on the use of hydrolysed and saponified cooking oils, or other waste oils, for PHA production [31-34]. Surprisingly, none of these studies have examined the ability of the strains to grow to high cell density on the hydrolysed substrates, nor have they achieved high PHA productivity.

The aim of the current study was to develop a bioprocess to achieve high cell density and high medium chain length PHA (mclPHA) productivity using the fatty acid fraction of hydrolysed waste cooking oil as the sole carbon source and P. putida KT2440, a generally recognised as safe (GRAS) and robust organism used in many biotechnological applications [35]. We also examined the properties of the mclPHA polymer accumulated during this bioprocess.

\section{Results}

\subsection{Fatty Acid Composition of Hydrolysed Waste Cooking Oil (HWCO)}

Hydrolysed waste cooking oil (HWCO) was separated into the glycerol and fatty acid fractions using a separation funnel. The fatty acid fraction of hydrolysed waste cooking oil (HWCOFA) contained predominantly oleic and linoleic acid (Figure 1). The high content of C18:2 and C18:1 is in keeping with previously reported contents of fatty acids in waste cooking oils [36-38]. The HWCOFA also had a relatively high content of saturated C16 fatty acid, which makes the hydrolysed oil solid at room temperature. This poses challenges for feeding to a bioreactor and bioavailability in an aqueous growth medium. To address the feeding challenge, the HWCOFA mixture was maintained at a temperature of $40{ }^{\circ} \mathrm{C}$ so that it could be poured into the bioreactor. 


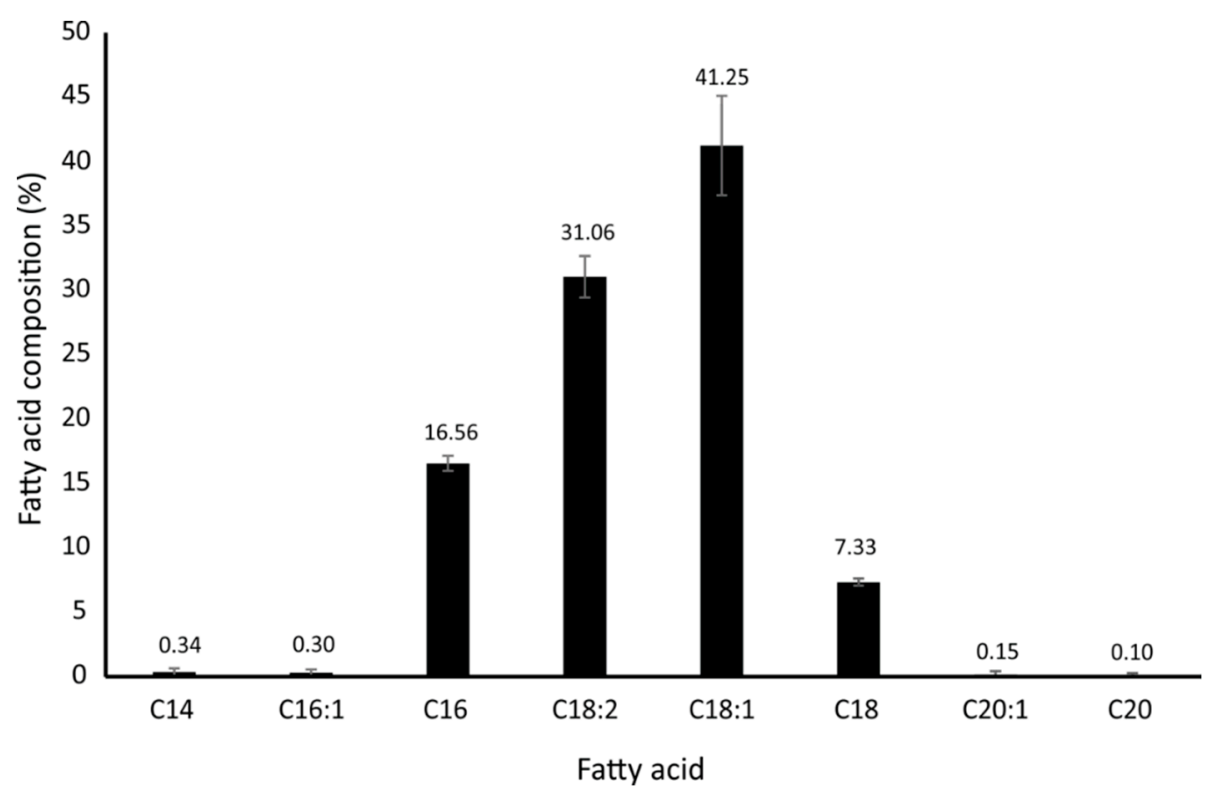

Figure 1. Fatty acid composition (expressed as a \% of total fatty acids present) of hydrolysed waste cooking oil (HWCO) analysed by GC/MS. C14-myristic acid; C16:1—palmitoleic acid; C16-palmitic acid; C18:2-linolelaidic acid; C18:1-oleic acid; C18—stearic acid; C20:1—gondoic acid; and C20-arachidic acid. The error bar represents standard deviation among three separate hydrolysis experiments.

\subsection{Bioprocess Development Using HWCOFA Mixture as the Carbon and Energy Source}

In order to develop a robust growth of P. putida KT2440 in a bioreactor using hWCO as carbon substrate, three fed batch strategies were undertaken. All fermentations had the same concentration of $12 \mathrm{~g} / \mathrm{l} \mathrm{HWCOFA}$ at the time of inoculation. Cells were incubated for three hours before any additional HWCOFA was supplied to the bioreactor. The first feed strategy (FS1) is based on the supply of substrate through a pulse feed starting with $12 \mathrm{~g}$ of HWCOFA at T3, followed by pulses of the same amount of HWCOFA at T5, T6, and T7 hours (Figure 2). Over the next two hours the pulse feeds were $18 \mathrm{~g}$ and $24 \mathrm{~g}$, followed by a $30 \mathrm{~g}$ pulse at T11, a $34 \mathrm{~g}$ pulse at T12, two $35 \mathrm{~g}$ pulses at T13 and T14, and two $40 \mathrm{~g}$ pulses at T15 and T16 (Figure 2). Between T17 and T25, 10 pulses of $45 \mathrm{~g}$ of HWCOFA were fed. This was followed by $48 \mathrm{~g}$ pulses at time 26 and 27 hours, and finally $50 \mathrm{~g}$ and $55 \mathrm{~g}$ at time 28 and 29 hours, respectively (Figure 2). This feed strategy was based on a feed strategy for nonanoic acid and designed to delay oxygen limitation typically occurring at high cell density growth [39]. The dissolved oxygen in the liquid medium was used as a tool to determine when substrate feeding should occur, and in this strategy, the dissolved oxygen was kept below 5\%. A total of $967 \mathrm{~g}$ of HWCOFA were supplied over a $30 \mathrm{~h}$ incubation, with P. putida KT2440 achieving a final CDW of $115 \mathrm{~g} / \mathrm{l}$ (Figure 3). 


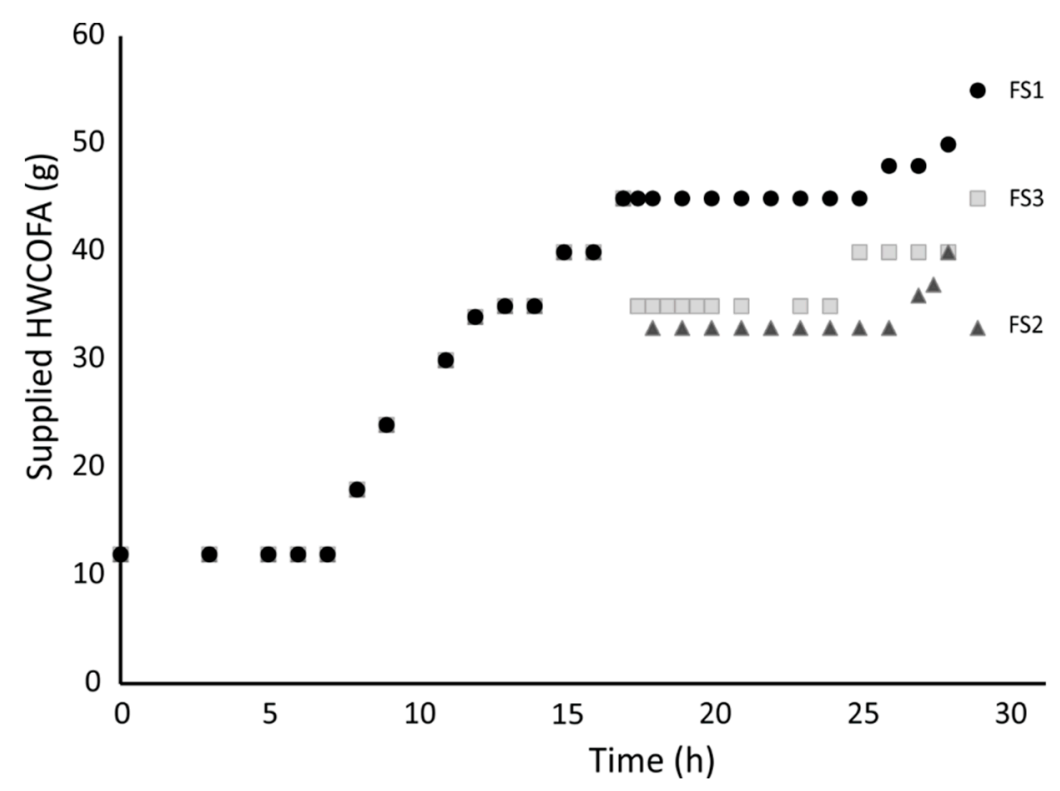

Figure 2. Hydrolysed waste cooking oil fatty acids (HWCOFA) pulse feeding strategies. Feed strategies FS2 and FS3 have the same feed profile as FS1 up to T17 hours after, at which time the number of pulses and the amount of HWCOFA supplied was different to FS1. FS1 supplied a total of $967 \mathrm{~g}$ of HWCOFA, FS2 $804 \mathrm{~g}$ of HWCOFA, and FS3 $844 \mathrm{~g}$ of HWCO, in $30 \mathrm{~h}$ fermentation. The starting volume of the culture was 31 , which increased to 4.21 for FS1 and FS3 and to 4.11 for FS2.

We have observed that the growth rate started to slow at 19 hours (Figure 3). Therefore, we designed a second feed strategy (FS2), building on the FS1. The substrate was supplied to the same amount until T17 hours, followed by 9 pulses of $33 \mathrm{~g}$ of HWCOFA until T26 hours, and pulses of $36 \mathrm{~g}, 37 \mathrm{~g}, 40 \mathrm{~g}$, and $33 \mathrm{~g}$ at T27, T27.5, T28, and T39 (Figure 2). FS2 supplied a total of $804 \mathrm{~g}$ of HWCOFA, achieving a final biomass of $145 \mathrm{~g} / \mathrm{l}$ with a delayed onset of the stationary phase observed (Figure 3). The final strategy, FS3, was also an adaptation of FS1 with the same amount of HWCOFA supplied to the bioreactor up to 17 hours, followed by nine $35 \mathrm{~g}$ pulses between T17.5 and T23, four pulses of $40 \mathrm{~g}$ between T2 4 and T28, and a final $45 \mathrm{~g}$ pulse at T29 (Figure 2). The total HWCOFA supplied to the fermentation medium was $844 \mathrm{~g}$, which resulted in a final CDW of $159 \mathrm{~g} / \mathrm{l}$ (Figure 3). PHA accumulation was detected after approximately 10 hours of incubation and linearly increased for longer in FS2 and FS3 (Figure 4). The highest substrate to biomass yield of was achieved with FS3 resulting in 1.5-fold improvement compared to FS1, while substrate to PHA yield increased 1.9-fold, with FS3 compared to FS1 (Table 1). Interestingly, the PHA content of cells decreased towards the end of the bioprocess with FS2 and FS3 (Figure 4), but without the corresponding drop in biomass (Figure 2). 


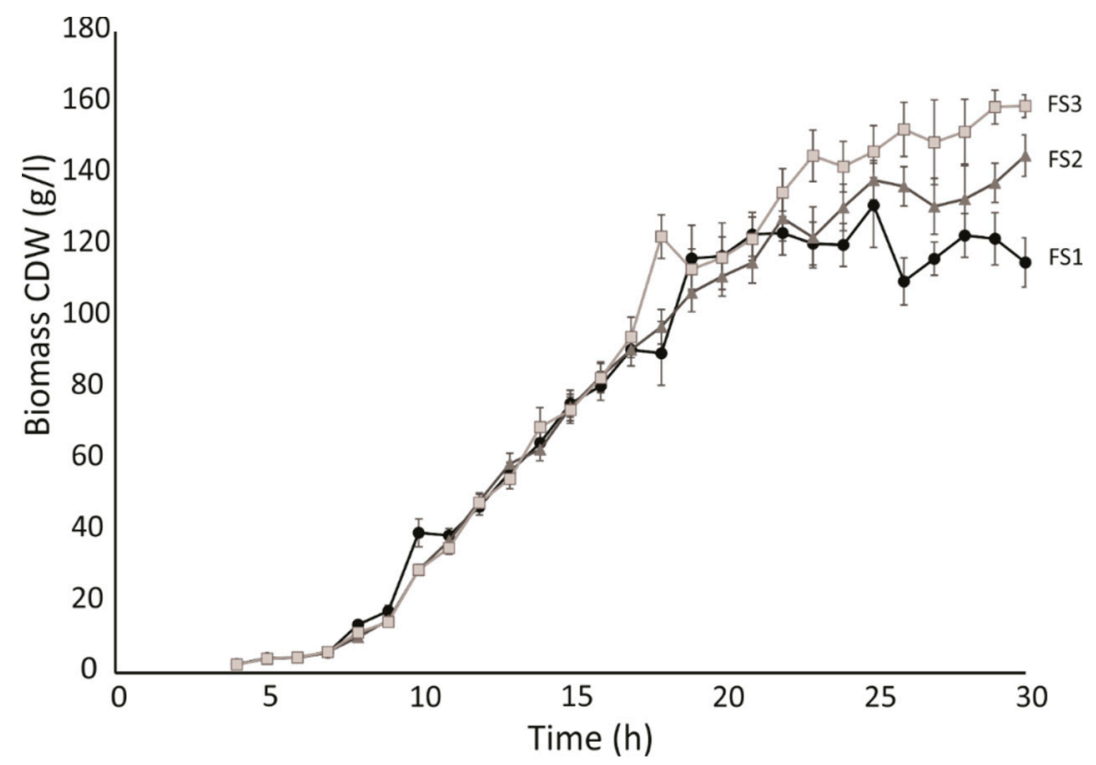

Figure 3. Growth of P. putida KT2440 on hydrolysed waste cooking oil fatty acids (HWCOFA) using three different feed strategies: FS1, FS2, and FS3. Biomass is represented as cell dry weight (CDW; g/l). Data are the average of three independent biological replicates and the error bars represent standard deviation among these.

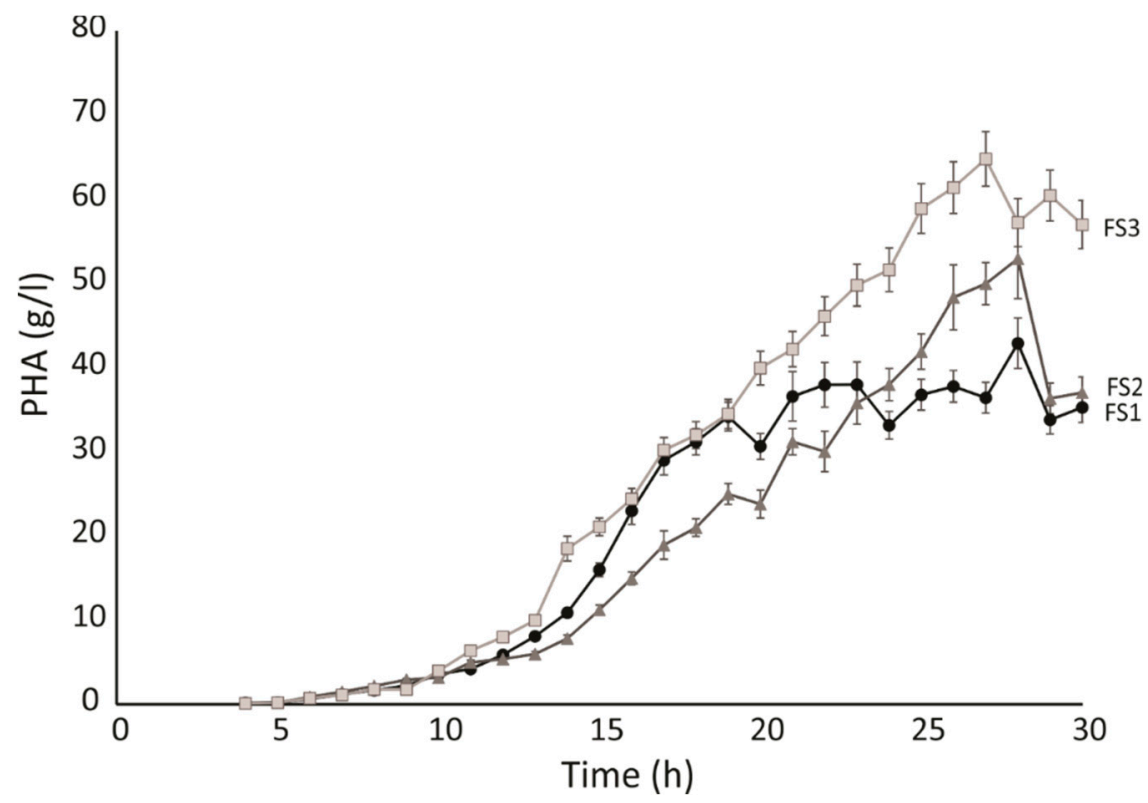

Figure 4. The dynamics of PHA (g/l) accumulation by P. putida KT2440 resulting from feed strategies FS1, FS2, and FS3. The error bars represent standard deviation among three independent biological replicates. 
Table 1. Growth data for P. putida KT2440 using different feeding strategies.

\begin{tabular}{|c|c|c|c|c|c|c|}
\hline Substrate & Feed Strategy & Initial Volume (1) & $\begin{array}{c}\text { Total Substrate Used } \\
\text { (g) }\end{array}$ & Final CDW (g/l) & Final Volume (1) & Total Biomass (g) \\
\hline \multirow{3}{*}{ HWCOFAs * } & 1 & 3 & 967 & 115.1 & 4.2 & 483.4 \\
\hline & Final PHA (\%CDW) & Final PHA (g/l) & $\begin{array}{l}\text { PHA productivity } \\
\text { (g/l/h) }\end{array}$ & $\begin{array}{l}\text { Total PHA produced } \\
\text { (g) }\end{array}$ & Biomass Yield (g/g) & PHA Yield (g/g) \\
\hline & 30.6 & 35.2 & 1.17 & 147.9 & 0.50 & 0.15 \\
\hline \multirow{4}{*}{ HWCOFAs } & Feed strategy & Initial Volume (1) & $\begin{array}{l}\text { Total substrate used } \\
\text { (g) }\end{array}$ & Final CDW (g/l) & Final Volume (1) & Total Biomass (g) \\
\hline & 2 & 3 & 804 & 145.2 & 4.1 & 595.3 \\
\hline & Final PHA (\%CDW) & Final PHA (g/l) & $\begin{array}{l}\text { PHA productivity } \\
(\mathrm{g} / \mathrm{l} / \mathrm{h})\end{array}$ & $\begin{array}{l}\text { Total PHA produced } \\
\text { (g) }\end{array}$ & Biomass Yield (g/g) & PHA Yield (g/g) \\
\hline & 25.5 & 37.0 & 1.23 & 151.8 & 0.74 & 0.19 \\
\hline \multirow{4}{*}{ HWCOFAs } & Feed strategy & Initial Volume (1) & $\begin{array}{l}\text { Total substrate used } \\
\text { (g) }\end{array}$ & Final CDW (g/l) & Final Volume (1) & Total Biomass (g) \\
\hline & 3 & 3 & 881 & 159.4 & 4.2 & 669.5 \\
\hline & Final PHA (\%CDW) & Final PHA (g/l) & $\begin{array}{l}\text { PHA productivity } \\
(\mathrm{g} / \mathrm{l} / \mathrm{h})\end{array}$ & $\begin{array}{l}\text { Total PHA produced } \\
\text { (g) }\end{array}$ & Biomass Yield (g/g) & PHA Yield (g/g) \\
\hline & 36.4 & 58.0 & 1.93 & 243.7 & 0.76 & 0.28 \\
\hline
\end{tabular}

${ }^{*}$ HWCOFAs: hydrolysed waste cooking oil fatty acids. Data are the average of three independent biological replicates (SD $\left.<5 \%\right)$. 


\subsection{Polymer Analysis}

The specific industrial application of PHAs is determined by the mechanical and thermal properties of the biopolymer. These characteristics are affected by the monomer composition, which varies according to the metabolic machinery of the organisms and the substrate supplied [40,41].

The polymer accumulated by P. putida KT2440 using HWCOFA is sticky, waxy, and has low molecular weight (Table 2). It contained $42 \mathrm{~mol} \%$ of $(R)-3$-hydroxydecanoic acid, $39 \mathrm{~mol} \%$ of $(R)$-3hydroxyoctanoic acid, $8 \mathrm{~mol} \%$ of (R)-3-hydroxydodecanoic acid, $6 \mathrm{~mol} \%$ of (R)-3-hydroxyundodecanoic acid, and $5 \mathrm{~mol} \%$ of $(R)$-3-hydroxyhexanoic acid. The polydispersity value of just under 2 is typical for mclPHAs (Table 2). Thermal analysis showed a similar low glass transition temperature for both polymers (Table 2). These properties indicate the polymer could be useful for adhesive applications.

Table 2. Properties of PHA polymer extracted from P. putida KT2440 grown on hydrolysed waste cooking oil fatty acids (HWCOFAs).

\begin{tabular}{cccccc}
\hline Substrate Conditions & $\operatorname{Td}\left({ }^{\circ} \mathbf{C}\right)$ & $\operatorname{Tg}\left({ }^{\circ} \mathbf{C}\right)$ & $\operatorname{Tm}\left({ }^{\circ} \mathbf{C}\right)$ & Mn & Mw \\
\hline HWCOFAs & $270.61 \pm 1.6$ & $-56.1 \pm 0.5$ & $20.7 \pm 0.5$ & $22954 \pm 975$ & $45317 \pm 62$ \\
\hline Td-thermal degradation temperature; & Tg-glass & transmission & temperature; & Tm-melting & temperature;
\end{tabular}

$\mathrm{Mn}$-number; $\mathrm{Mw}-$ molecular weight.

\section{Discussion}

We have developed a successful bioprocess for the high cell density conversion of HWCOFA into mclPHA with high PHA volumetric productivity (Table 1). WCO represents a major pollutant due to the poor end-of-life management [42]. The dominant route for the WCO management is incineration, which leads to the loss of the valuable resource [43]. The bioprocess reported here contributes to the end-of-life management through valorisation of this waste material and production of a biodegradable polymer.

While the use of modelling informs the strategy to optimise processes and reduces unnecessary experimentation [44], the building of the model depends upon the accurate measurement of variables, such as substrate concentration. Long-chain length fatty acids such as those found in HWCO are insoluble in water [45]. The hydrophobicity of the fatty acids results in a lack of uniformity in their dispersion in an aqueous medium and the sticking of fatty acids to the wall of the bioreactor. Thus, it was not possible to accurately measure substrate utilisation and a mathematical model of the process could not be constructed. Therefore, an empirical approach was taken in developing a bioprocess for conversion of HWCOFA to mclPHA. Oxygen limitation is a typical reason for termination of aerobic high cell density fermentations, causing the onset of the stationary phase [39]. Oxygen uptake rate is proportional to the cell generation rate, and therefore a gradual decrease in growth rate by decaying the amount of substrate fed should result in high cell density while avoiding the negative physiological effects of growth halt. To initiate the fed batch fermentation, $12 \mathrm{~g} / \mathrm{l}$ of HWCOFA was used as the starting concentration, as this is known to be below the inhibitory concentration of fatty acid substrates [46]. The fed batch process began with the first feed of HWCOFAs $3 \mathrm{~h}$ after inoculation. The rate of substrate feeding then was varied by increasing amounts of the fed substrate, followed by constant feed of the substrate throughout the exponential to early stationary phase (Figure 2). Decaying feeds in FS2 and FS3 caused a delayed onset of stationary phase, and therefore higher final biomass (Figure 3). Decaying feeds also resulted in increased PHA accumulation, likely due to preventing the accumulation of the inhibitory level of fatty acids.

Another challenge we encountered when developing this bioprocess was foaming. The same issue was described when crude fatty acids were supplied as a carbon substrate in bioreactors at concentrations greater than $10 \mathrm{~g} / \mathrm{l}$ [31]. Thus the implementation of this technology at scale will require good foam breakage and dispersion. 
High PHA productivity when fatty acids are used as a substrate was reported earlier. Lee and co-workers observed Aeromonas hydrophila cells with $45.2 \%$ of the CDW as PHA accumulation, and a PHA productivity of $1.01 \mathrm{~g} / \mathrm{l} / \mathrm{h}$ with lauric acid and oleic acid [47]. P. putida KT2442 grown on oleic acid and P. putida KT2440 grown on nonanoic acid have achieved productivities at $1.9 \mathrm{~g} / \mathrm{l} / \mathrm{h}$ and $2.3 \mathrm{~g} / \mathrm{l} / \mathrm{h}$, respectively $[39,47]$. In this work, when HWCOFA was used as a substrate, the PHA volumetric productivity was $1.9 \mathrm{~g} / \mathrm{l} / \mathrm{h}$ (Table 1 ). Thus, low cost HWCOFA show as much potential for PHA production as more expensive virgin fatty acids.

While a number of studies investigated the production of mclPHAs from vegetable oils, waste cooking oils, and saponified waste palm oil [48-51], this is the first study to use HWCOFA for mclPHA production, with high cell density and high PHA productivity in a bioreactor. For example, a mixture of glucose and $2 \%$ free fatty acids was used for the growth and PHA accumulation by P. aeruginosa 47T2 in shaken flasks [52]. While achieved PHA levels were comparable between this and our study, the biomass (7.9 $\mathrm{g} / \mathrm{l} \mathrm{CDW})$ reported by Haba et al. [52] is 18.7-fold lower than the biomass achieved in the present study. Similarly, the ability of P. oleovorans, P. resivorans, and P. putida to produce mclPHA from tallow was demonstrated only at low cell density [53]. Conversion of saponified waste palm oil as the sole source of carbon and energy into PHA in a bioreactor by Pseudomonas sp. Gl01 was reported by Możejko and Ciesielski [51]. However, our bioprocess based on FS3 achieves 33-fold higher PHA productivity compared to productivity reported by Możejko and Ciesielski [51].

The vast majority of studies report on the need for inorganic nutrient limitation in order to observe PHA accumulation in Pseudomonas and other strains [24,54,55]. In the current study, P. putida KT2440 accumulated PHA early in the growth cycle when no inorganic nutrient limitation occurred. The fatty acids present in HWCO feed directly into beta-oxidation. The resultant intermediates are PHA precursors. Given the high energy state of cells as a result of growth on long chain fatty acids and the presence of precursors in the cell it is not surprising that we observed PHA accumulation, as the conditions for accumulation of PHA were ideal.

PHA accumulated by bacteria supplied with vegetable oil derived free fatty acids and animal fat derived free fatty acids display liquid properties at room temperature similar to the polymers arising from the supply of HWCOFAs to bacteria in the current study $[21,56]$. These polymer properties can be explained by the high degree of disorder and by the long chain monomers acting as internal plasticisers [30]. However, the molecular weight (Mw) of PHA polymers accumulated by Pseudomonas species supplied with other fatty acid substrates, such as oleic acid, lauric acid [57], and mystiric acid [34], were between 2 and 4.2-fold higher than those seen in our study.

In conclusion, we have developed a high cell density cultivation with the highest known PHA productivity bioprocess using WCO as a source of waste fatty acids. The PHA productivity is similar to that achieved with pure single source fatty acids $[28,34,47]$ and shows great promise for process scale up and polymer product development.

\section{Materials and Methods}

\subsection{Bacterial Growth Medium \& Strain Maintenance}

Minimal Salt Medium (MSM) was used as the growth medium for all strains in shaken flask experiments. This medium contains (per litre): $9 \mathrm{~g} \mathrm{Na}_{2} \mathrm{HPO}_{4} \times 12 \mathrm{xH}_{2} 0,1.5 \mathrm{~g} \mathrm{KH}_{2} \mathrm{PO}_{4}, 1 \mathrm{~g} \mathrm{NH}_{4} \mathrm{Cl}$, $200 \mu \mathrm{g} \mathrm{MgSO}_{4}$, and $1000 \mu \mathrm{L}$ trace elements solution. The trace elements solution contained (per litre in $1 \mathrm{M} \mathrm{HCl}): 4 \mathrm{~g} \mathrm{ZnSO}_{4 \times} 7 \mathrm{H}_{2} 0,10 \mathrm{~g} \mathrm{FeSO}_{4} \times 7_{2} 0,1 \mathrm{~g} \mathrm{CuCl}_{2} \times 2 \mathrm{H}_{2} 0,1 \mathrm{~g} \mathrm{MnCl}_{2 \times} 4 \mathrm{H}_{2} 0,1 \mathrm{~g} \mathrm{Na}_{2} \mathrm{~B}_{4} \mathrm{O}_{\chi} 10 \mathrm{H}_{2} \mathrm{O}$, $0.2 \mathrm{~g} \mathrm{NiCl}_{2 \times} 6 \mathrm{H}_{2} 0$, and $0.3 \mathrm{~g} \mathrm{Na} 2 \mathrm{MoO}_{4} \times 2 \mathrm{H}_{2} 0$. Pseudomonas putida KT2440 [ATCC ${ }^{\circledR} 47054^{\mathrm{TM}}$ ] was grown on Pseudomonas isolation agar (PIA) (Fluka analytical).

\subsection{Waste Cooking Oil (WCO) Hydrolysis}

The WCO was supplied by Frylite ${ }^{\circledR}$ (Dublin, Ireland). A measure of $100 \mathrm{~g}$ of WCO was hydrolysed using $100 \mathrm{~mL}$ of $6 \mathrm{M} \mathrm{NaOH}$. The mixture was heated at $60^{\circ} \mathrm{C}$ for $90 \mathrm{~min}$. The resultant saponified fatty 
acid mixture was precipitated through the addition of $400 \mathrm{~mL}$ of $6 \mathrm{M} \mathrm{HCl}$. The mixture was decanted into a separating funnel and the fatty acid phase separated from the aqueous phase, containing salts and glycerol. The fatty acid phase was washed with approximately $1000 \mathrm{~mL}$ of distilled water, filtered using a vacuum system (Fisher FB59037 Range QL100, Dublin, Ireland), and supplied as the sole carbon and energy substrate in fermentations.

\subsection{Fermentation Conditions}

A single colony of P. putida KT2440 from a PIA plate was inoculated into $50 \mathrm{~mL}$ Minimal Salt Media (MSM) in flask experiments, as previously described [58]. Flasks were supplemented with $3 \mathrm{~g} / \mathrm{l}$ of technical oleic acid (Sigma Aldrich, Dublin, Ireland). Flasks were incubated at $30^{\circ} \mathrm{C}$, shaking at $200 \mathrm{rpm}$ for $16-18 \mathrm{~h}$. Four $50 \mathrm{~mL}$ cultures of P. putida KT2440 overnights were prepared for inoculation into a fermenter.

Fermentations were performed in a Biostat B+ bioreactor with a 5 litre working volume (Sartorius). MSM was used as the base media for all fermentations. The fermentations had an initial volume of 3 litres, with an initial agitation of $500 \mathrm{rpm}$. The temperature was maintained at $30^{\circ} \mathrm{C}$ and $\mathrm{pH}$ was controlled at $6.9+/-0.1$ by the addition of $20 \% \mathrm{NH}_{4} \mathrm{OH}$ solution or $15 \%(\mathrm{v} / \mathrm{v}) \mathrm{H}_{2} \mathrm{SO}_{4}$. The $\mathrm{NH}_{4} \mathrm{OH}$ also acted as a nitrogen source. Foaming was controlled by the addition of antifoam solution (polypropylene glycol P2000, Sigma). Dissolved oxygen (DO) was set at $20 \%$ of saturation and was increased by increasing agitation. $\mathrm{O}_{2}$ was supplied as air at a constant flow rate of 5 litres per minute. To start, the fermentation substrate was supplied at a concentration of $12 \mathrm{~g} / \mathrm{l}$. Three pulse feeding strategies for HWCOFA were undertaken and are described in the results section.

\subsection{Analysis of Fatty Acids in Hydrolysed Waste Cooking Oil}

Fatty acids generated by hydrolysis of WCO and virgin plant oil standards (Sigma Aldrich) were derivatised with $\mathrm{N}$-Methyl-N-(trimethylsilyl)trifluoroacetamide (TMS). A measure of $2 \mathrm{~mL}$ of chloroform was placed in a gas chromatography vial. Then, $1 \mu \mathrm{L}$ of the substrate and $20 \mu \mathrm{L}$ of TMS were added. The vial was incubated at $70^{\circ} \mathrm{C}$ for $30 \mathrm{~min}$. The fatty acids were then analysed using an Agilent $6890 \mathrm{~N}$ gas chromatograph (GC) (Cork, Ireland) fitted with a 5973 series inert mass spectrophotometer (MS). A HP-5 column $(12 \mathrm{~m} \times 0.2 \mathrm{~mm} \times 0.33 \mu \mathrm{m}$; Hewlett Packard $)$ was used with an oven method of $50{ }^{\circ} \mathrm{C}$ for $3 \mathrm{~min}$, increasing by $10^{\circ} \mathrm{C} / \mathrm{min}$ to $250^{\circ} \mathrm{C}$ and holding for $1 \mathrm{~min}$. A 10:12 split was used with helium as the carrier gas and an inlet temperature of $250^{\circ} \mathrm{C}$.

\subsection{PHA Content and Monomer Composition Determination}

Determination of the PHA content of cells and monomer composition of PHA was determined by subjecting lyophilised cells to acidic methanolysis [59,60]. Dried cells were weighed (5 to $10 \mathrm{mg}$ ) and suspended in $2 \mathrm{~mL}$ of acidified methanol $\left(15 \% \mathrm{H}_{2} \mathrm{SO}_{4}, \mathrm{v} / \mathrm{v}\right)$ and $2 \mathrm{~mL}$ of chloroform, containing $6 \mathrm{mg} / \mathrm{l}$ benzoate methyl ester as an internal standard. The solution was placed in $15 \mathrm{ml}$ Pyrex test tubes, sealed, and incubated at $100{ }^{\circ} \mathrm{C}$ for $3 \mathrm{~h}$. The tubes were then placed on ice for $1 \mathrm{~min}$. A meausre of $1 \mathrm{~mL}$ of water was added to each tube, and the solution was mixed by vigorous vortexing for $1 \mathrm{~min}$. The phases were allowed to separate, and the organic phase was removed and passed through a filter before further analysis. The 3-hydroxyalkanoic acid methyl esters were analysed by gas chromatography (GC) using an Agilent 6890N chromatograph equipped with a HP Innowax column $(30 \mathrm{~m} \times 0.25 \mathrm{~mm} \times$ $0.5 \mu \mathrm{m}$ ) and a flame ionisation detector (FID). An oven ramp cycle was employed as follows: $120^{\circ} \mathrm{C}$ for $5 \mathrm{~min}$, increasing by $3^{\circ} \mathrm{C} / \mathrm{min}$ to $180^{\circ} \mathrm{C}$, and at $180^{\circ} \mathrm{C}$ for $10 \mathrm{~min}$. A $20: 1$ split was used with helium as the carrier gas and an inlet temperature of $250^{\circ} \mathrm{C}$. Commercially available 3-hydroxyalkanoic acids (Bioplastech Ltd Dublin Ireland) were methylated as described above for PHA isolated from P. putida KT2440, and they were used as standards to identify individual PHA monomers. The unsaturated monomers were detected using the programme described for the analysis of fatty acids. 


\subsection{Nutrient and Biomass Analysis}

Samples were taken at 1 or $2 \mathrm{~h}$ intervals during the fermentations. Two $2 \mathrm{~mL}$ samples were taken and centrifuged at $17.960 \times g$ for $3 \mathrm{~min}$. The supernatant was decanted into a separate tube, and the cell pellets and supernatant were frozen at $-80^{\circ} \mathrm{C}$. Cell dry weight $(\mathrm{CDW})$ was determined by first freezing the cell pellet and then lyophilising (freeze-drying) the cell pellet at $-80^{\circ} \mathrm{C}$ overnight and subsequently weighing the cells. For cultures grown in a $50 \mathrm{~mL}$ flask, cell suspensions were centrifuged at $3,220 \times g$ for $10 \mathrm{~min}$, and $2 \mathrm{~mL}$ of supernatant was retained and the remainder discarded. Pellets were resuspended in $1 \mathrm{~mL}$ of DI water and then transferred into Eppendorf tubes. These were then centrifuged at $17.960 \times \mathrm{g}$ for $3 \mathrm{~min}$; the supernatant was discarded and the pellets treated as the samples from the bioreactor. The concentration of nitrogen in the supernatant was determined using the method described by Scheiner [61]. The soluble inorganic phosphate concentration was determined using the USA EPA colorimetric method (USEPA, 1978).

\subsection{Polymer Isolation}

Cells were harvested from the bioreactor in a Sorvall centrifuge (Fisher Scientific, Dublin, Ireland) at $25,040 \mathrm{~g}$. Harvested cells were frozen at $-80^{\circ} \mathrm{C}$ for $24 \mathrm{~h}$ and then lyophilised (Labconco, Fisher Scientific). PHA was isolated from freeze-dried cells using room temperature acetone. This involved the stirring of $10 \mathrm{~g}$ of cells suspended in $100 \mathrm{~mL}$ acetone for $24 \mathrm{~h}$. The mixture was allowed to settle, and the supernatant was filtered using a $0.2 \mu \mathrm{m}$ PTFE filter. Acetone containing PHA was then subjected to rotary evaporation under vacuum until approximately $90 \mathrm{~mL}$ of acetone had been recovered. The polymer was precipitated using 2 vol of a wash solution consisting of 35\% methanol, 35\% ethanol, and $30 \%$ distilled water [62]. The supernatant was then decanted, and the precipitated PHA was allowed to dry before further analysis.

\subsection{PHA Characterisation}

\subsubsection{Gel Permeation Chromatography (GPC)}

The average molecular weight $(\mathrm{Mw})$, the molecular number $(\mathrm{Mn})$, and the polydispersity index (PD) of the polymer were measured by GPC using PL gel $5 \mathrm{~mm}$ mixed-C +PL gel column (Perkin-Elmer, Dublin, Ireland)) with the PELV $290 \mathrm{UV}$-vis detector set at $254 \mathrm{~nm}$. Spectroscopic grade chloroform was used as the eluent flow rate of $1.0 \mathrm{~mL} / \mathrm{min}$. A sample concentration of $1 \%(\mathrm{w} / \mathrm{v})$ and injection volumes of $500 \mu \mathrm{L}$ were used. A molecular weight calibration curve was generated with polystyrene standards with low polydispersity [63].

\subsubsection{Differential Scanning Calorimetry (DSC)}

The polymer was analysed by DSC (Perkin-Elmer, Dublin,) with a Perkin-Elmer Pyris Diamond calorimeter calibrated to Indium standards to determine the glass transition temperature (Tg), melting temperature $(\mathrm{Tm})$, and degradation temperature $(\mathrm{Td})$. The samples were encapsulated in hermetically sealed aluminium pans and heated from $-70{ }^{\circ} \mathrm{C}$ to $100{ }^{\circ} \mathrm{C}$ at a rate of $10^{\circ} \mathrm{C} / \mathrm{min}$. To determine the glass transition temperature ( $\mathrm{Tg}$ ) the samples were held at $100{ }^{\circ} \mathrm{C}$ for $1 \mathrm{~min}$ and rapidly quenched to $-70{ }^{\circ} \mathrm{C}$. The samples were then reheated from -70 to $100{ }^{\circ} \mathrm{C}$ at $10{ }^{\circ} \mathrm{C} / \mathrm{min}$ to determine the melting temperature $(\mathrm{Tm})$ and glass transition temperature $(\mathrm{Tg})$. Finally, the samples were heated to $350{ }^{\circ} \mathrm{C}$ at a rate of $10{ }^{\circ} \mathrm{C} / \mathrm{min}$ to determine the thermal destruction temperature (Td) [63].

Author Contributions: Conceptualization, S.T.K. and K.E.O.; Funding acquisition, K.E.O.; Investigation, C.R., R.B.P., and M.W.; Methodology, C.R., S.T.K., and T.N.; Supervision, S.T.K., T.N., and K.E.O.; Validation, K.E.O.; Writing-original draft, C.R.; Writing-review \& editing, S.T.K., T.N. and K.E.O.

Acknowledgments: Carolina Ruiz and this work were funded by Coordenação de Aperfeiçoamento de Pessoal de Nivel Superior (CAPES), Brazil.

Conflicts of Interest: The authors declare no conflict of interest. 


\section{References}

1. Keshavarz, T.; Roy, I. Polyhydroxyalkanoates: bioplastics with a green agenda. Curr. Opin. Microbiol. 2010, 13, 321-326. [CrossRef]

2. Plastics Europe. Plastics-The Facts 2017; 2017. Available online: https://www.plasticseurope.org/en/ resources/publications/274-plastics-facts-2017 (accessed on 23 April 2019).

3. Narancic, T.; O'Connor, K.E. Plastic waste as a global challenge: are biodegradable plastics the answer to the plastic waste problem. Microbiology 2019, 165, 129-137. [CrossRef]

4. System Initiative on Environment and Natural Resource Security. The New Plastics Economy: Catalysing action. World Economic Forum: 2017. Available online: https://www.ellenmacarthurfoundation.org/ publications/new-plastics-economy-catalysing-action.

5. Hanke, G. Marine Beach Litter in Europe-Top Items; Joint Research Centre, European Commission, 2016; Available online: https://mcc.jrc.ec.europa.eu/documents/Marine_Litter/MarineLitterTOPitems_final_24.1. 2017.pdf.

6. Rochman, C.M.; Browne, M.A.; Halpern, B.S.; Hentschel, B.T.; Hoh, E.; Karapanagioti, H.K.; Rios-Mendoza, L.M.; Takada, H.; Teh, S.; Thompson, R.C. Classify plastic waste as hazardous. Nature 2013, 494, 169-171. [CrossRef] [PubMed]

7. Rochman, C.M.; Hoh, E.; Kurobe, T.; Teh, S.J. Ingested plastic transfers hazardous chemicals to fish and induces hepatic stress. Sci. Rep. 2013, 3, 1-7. [CrossRef] [PubMed]

8. Wilcox, C.; Van Sebille, E.; Hardesty, B.D. Threat of plastic pollution to seabirds is global, pervasive, and increasing. Proc. Natl. Acad. Sci. USA 2015, 112, 11899-11904. [CrossRef] [PubMed]

9. Mecking, S. Nature or petrochemistry? Biologically degradable materials. Angew. Chem. Int. Ed. 2004, 43, 1078-1085. [CrossRef]

10. Babu, R.P.; O'Connor, K.; Seeram, R. Current progress on bio-based polymers and their future trends. Prog. Biomater. 2013, 2, 8. [CrossRef]

11. Mohanty, A.K.; Misra, M.; Drzal, L.T. Sustainable bio-composites from renewable resources: Opportunities and challenges in the green materials world. J. Polym. Environ. 2002, 10, 19-26. [CrossRef]

12. Harmsen, P.F.H.; Hackmann, M.M.; Bos, H.L. Green building blocks for bio-based plastics. Biofuel Bioprod. Bior. 2014, 8, 306-324. [CrossRef]

13. Isikgor, F.H.; Becer, C.R. Lignocellulosic biomass: a sustainable platform for the production of bio-based chemicals and polymers. Polym. Chem. 2015, 6, 4497-4559. [CrossRef]

14. Sudesh, K.; Abe, H.; Doi, Y. Synthesis, structure and properties of polyhydroxyalkanoates: Biological polyesters. Prog. Polym. Sci. 2000, 25, 1503-1555. [CrossRef]

15. Malacara, C.F.P.; Romero, A.G.; Ponce, M.M.; Marenco, T.C. Approaches for the synthesis of tailor-made polyhydroxyalkanoates. In Microbial Factories: Biodiversity, Biopolymers, Bioactive Molecules: Volume 2; Kalia, V.C., Ed.; Springer India: New Delhi, India; pp. 11-28. [CrossRef]

16. Kang, H.O.; Chung, C.W.; Kim, H.W.; Kim, Y.B.; Rhee, Y.H. Cometabolic biosynthesis of copolyesters consisting of 3-hydroxyvalerate and medium-chain-length 3-hydroxyalkanoates by Pseudomonas sp DSY-82. Anton. Leeuw. Int. J. G. 2001, 80, 185-191. [CrossRef]

17. Lenz, R.W.; Kim, Y.B.; Fuller, R.C. Production of unusual bacterial polyesters by Pseudomonas oleovorans through cometabolism. Fems Microbiol. Lett. 1992, 103, 207-214. [CrossRef]

18. Ashby, R.D.; Foglia, T.A. Poly(hydroxyalkanoate) biosynthesis from triglyceride substrates. Appl. Microbiol. Biot. 1998, 49, 431-437. [CrossRef]

19. Li, Z.B.; Loh, X.J. Water soluble polyhydroxyalkanoates: future materials for therapeutic applications. Chem. Soc. Rev. 2015, 44, 2865-2879. [CrossRef] [PubMed]

20. Vastano, M.; Pellis, A.; Immirzi, B.; Dal Poggetto, G.; Malinconico, M.; Sannia, G.; Guebitz, G.M.; Pezzella, C. Enzymatic production of clickable and PEGylated recombinant polyhydroxyalkanoates. Green. Chem. 2017, 19, 5494-5504. [CrossRef]

21. Walsh, M.; O'Connor, K.; Babu, R.; Woods, T.; Kenny, S. Plant oils and products of their hydrolysis as substrates for polyhydroxyalkanoate synthesis. Chem. Biochem. Eng. Q. 2015, 29, 123-133. [CrossRef]

22. Sabapathy, P.C.; Devaraj, S.; Kathirvel, P. Parthenium hysterophorus: low cost substrate for the production of polyhydroxyalkanoates. Curr. Sci. 2017, 112, 2106-2111. [CrossRef] 
23. Poblete-Castro, I.; Binger, D.; Oehlert, R.; Rohde, M. Comparison of mcl-Poly(3-hydroxyalkanoates) synthesis by different Pseudomonas putida strains from crude glycerol: citrate accumulates at high titer under PHA-producing conditions. BMC Biotechnol. 2014, 14. [CrossRef]

24. Ward, P.G.; Goff, M.; Donner, M.; Kaminsky, W.; O'Connor, K.E. A two step chemo-biotechnological conversion of polystyrene to a biodegradable thermoplastic. Environ. Sci. Technol. 2006, 40, 2433-2437. [CrossRef]

25. Maddikeri, G.L.; Pandit, A.B.; Gogate, P.R. Intensification approaches for biodiesel synthesis from waste cooking oil: A review. Ind. Eng. Chem. Res. 2012, 51, 14610-14628. [CrossRef]

26. Sanchez, R.J.; Schripsema, J.; da Silva, L.F.; Taciro, M.K.; Pradella, J.G.C.; Gomez, J.G.C. Medium-chain-length polyhydroxyalkanoic acids (PHA(mcl)) produced by Pseudomonas putida IPT 046 from renewable sources. Eur. Polym. J. 2003, 39, 1385-1394. [CrossRef]

27. Le Meur, S.; Zinn, M.; Egli, T.; Thony-Meyer, L.; Ren, Q. Production of medium-chain-length polyhydroxyalkanoates by sequential feeding of xylose and octanoic acid in engineered Pseudomonas putida KT2440. BMC Biotechnol. 2012, 12, 1-12. [CrossRef]

28. Sun, Z.; Ramsay, J.A.; Guay, M.; Ramsay, B. Increasing the yield of MCL-PHA from nonanoic acid by co-feeding glucose during the PHA accumulation stage in two-stage fed-batch fermentations of Pseudomonas putida KT2440. J. Biotechnol. 2007, 132, 280-282. [CrossRef]

29. Kim, B.S. Production of medium chain length polyhydroxyalkanoates by fed-batch culture of Pseudomonas oleovorans. Biotechnol. Lett. 2002, 24, 125-130. [CrossRef]

30. Kellerhals, M.B.; Kessler, B.; Witholt, B.; Tchouboukov, A.; Brandl, H. Renewable long-chain fatty acids for production of biodegradable medium-chain-length polyhydroxyalkanoates (mcl-PHAs) at laboratory and pilot plant scales. Macromolecules 2000, 33, 4690-4698. [CrossRef]

31. Annuar, M.S.M.; Tan, I.K.P.; Ibrahim, S.; Ramachandran, K.B. Production of medium-chain-length poly(3-hydroxyalkanoates) from crude fatty acids mixture by Pseudomonas putida. Food Bioprod Process 2007, 85, 104-119. [CrossRef]

32. Fernández, D.; Rodríguez, E.; Bassas, M.; Viñas, M.; Solanas, A.M.; Llorens, J.; Marqués, A.M.; Manresa, A. Agro-industrial oily wastes as substrates for PHA production by the new strain Pseudomonas aeruginosa NCIB 40045: Effect of culture conditions. Biochem. Eng. J. 2005, 26, 159-167. [CrossRef]

33. Mozejko, J.; Wilke, A.; Przybylek, G.; Ciesielski, S. Mcl-PHAs produced by Pseudomonas sp Gl01 using fed-batch cultivation with waste rapeseed oil as carbon source. J. Microbiol. Biotechn. 2012, 22, 371-377. [CrossRef]

34. Tan, I.K.P.; Kumar, K.S.; Theanmalar, M.; Gan, S.N.; Gordon, B. Saponified palm kernel oil and its major free fatty acids as carbon substrates for the production of polyhydroxyalkanoates in Pseudomonas putida PGA1. Appl. Microbiol. Biot. 1997, 47, 207-211. [CrossRef]

35. Belda, E.; van Heck, R.G.A.; Lopez-Sanchez, M.J.; Cruveiller, S.; Barbe, V.; Fraser, C.; Klenk, H.P.; Petersen, J.; Morgat, A.; Nikel, P.I.; et al. The revisited genome of Pseudomonas putida KT2440 enlightens its value as a robust metabolic chassis. Environ. Microbiol. 2016, 18, 3403-3424. [CrossRef] [PubMed]

36. Leung, D.Y.C.; Guo, Y. Transesterification of neat and used frying oil: Optimization for biodiesel production. Fuel Process Technol. 2006, 87, 883-890. [CrossRef]

37. Cruz, M.V.; Sarraguca, M.C.; Freitas, F.; Lopes, J.A.; Reis, M.A.M. Online monitoring of P(3HB) produced from used cooking oil with near-infrared spectroscopy. J. Biotechnol. 2015, 194, 1-9. [CrossRef]

38. Martino, L.; Cruz, M.V.; Scoma, A.; Freitas, F.; Bertin, L.; Scandola, M.; Reis, M.A.M. Recovery of amorphous polyhydroxybutyrate granules from Cupriavidus necator cells grown on used cooking oil. Int. J. Biol. Macromol. 2014, 71, 117-123. [CrossRef]

39. Maclean, H.; Sun, Z.Y.; Ramsay, J.; Ramsay, B. Decaying exponential feeding of nonanoic acid for the production of medium-chain-length poly(3-hydroxyalkanoates) by Pseudomonas putida KT2440. Can. J. Chem. 2008, 86, 564-569. [CrossRef]

40. Lemos, P.C.; Serafim, L.S.; Reis, M.A.M. Synthesis of polyhydroxyalkanoates from different short-chain fatty acids by mixed cultures submitted to aerobic dynamic feeding. J. Biotechnol. 2006, 122, 226-238. [CrossRef] [PubMed]

41. Zhila, N.; Shishatskaya, E. Properties of PHA bi-, ter-, and quarter-polymers containing 4-hydroxybutyrate monomer units. Int. J. Biol. Macromol. 2018, 111, 1019-1026. [CrossRef] 
42. Nantha Gopal, K.; Pal, A.; Sharma, S.; Samanchi, C.; Sathyanarayanan, K.; Elango, T. Investigation of emissions and combustion characteristics of a CI engine fueled with waste cooking oil methyl ester and diesel blends. Alex. Eng. J. 2014, 53, 281-287. [CrossRef]

43. Taniguchi, I.; Kagotani, K.; Kimura, Y. Microbial production of poly(hydroxyalkanoate)s from waste edible oils. Green Chem. 2003, 5, 545-548. [CrossRef]

44. Giridhar, R.; Srivastava, A.K. Fed-batch sorbose fermentation using pulse and multiple feeding strategies for productivity improvement. Biotechnol. Bioprocess Eng. 2000, 5, 340-344. [CrossRef]

45. Lie, E.; Molin, G. Hydrolysis and esterification with immobilized lipase on hydrophobic and hydrophilic zeolites. J. Chem. Technol. Biot. 1991, 50, 549-553. [CrossRef]

46. Lee, S.Y.; Wong, H.H.; Choi, J.I.; Lee, S.H.; Lee, S.C.; Han, C.S. Production of medium-chain-length polyhydroxyalkanoates by high-cell-density cultivation of Pseudomonas putida under phosphorus limitation. Biotechnol. Bioeng. 2000, 68, 466-470. [CrossRef]

47. Lee, S.H.; Oh, D.H.; Ahn, W.S.; Lee, Y.; Choi, J.I.; Lee, S.Y. Production of poly(3-hydroxybutyrate-co-3-hydroxyhexanoate) by high-cell-density cultivation of Aeromonas hydrophila. Biotechnol. Bioeng. 2000, 67, 240-244. [CrossRef]

48. Marsudi, S.; Unno, H.; Hori, K. Palm oil utilization for the simultaneous production of polyhydroxyalkanoates and rhamnolipids by Pseudomonas aeruginosa. Appl. Microbiol. Biot. 2008, 78, 955-961. [CrossRef] [PubMed]

49. Verlinden, R.A.J.; Hill, D.J.; Kenward, M.A.; Williams, C.D.; Piotrowska-Seget, Z.; Radecka, I.K. Production of polyhydroxyalkanoates from waste frying oil by Cupriavidus necator. AMB Exp. 2011, 1, 1-8. [CrossRef] [PubMed]

50. Yun, H.S.; Kim, D.Y.; Chung, C.W.; Kim, H.W.; Yang, K.Y.; Rhee, Y.H. Characterization of a tacky poly(3-hydroxyalkanoate) produced by Pseudomonas chlororaphis HS21 from palm kernel oil. J. Microbiol. Biotechn. 2003, 13, 64-69.

51. Mozejko, J.; Ciesielski, S. Saponified waste palm oil as an attractive renewable resource for mcl-polyhydroxyalkanoate synthesis. J. Biosci. Bioeng. 2013, 116, 485-492. [CrossRef] [PubMed]

52. Haba, E.; Vidal-Mas, J.; Bassas, M.; Espuny, M.J.; Llorens, J.; Manresa, A. Poly 3-(hydroxyalkanoates) produced from oily substrates by Pseudomonas aeruginosa 47T2 (NCBIM 40044): Effect of nutrients and incubation temperature on polymer composition. Biochem. Eng. J. 2007, 35, 99-106. [CrossRef]

53. Cromwick, A.M.; Foglia, T.; Lenz, R.W. The microbial production of poly(hydroxyalkanoates) from tallow. Appl. Microbiol. Biot. 1996, 46, 464-469. [CrossRef]

54. Tobin, K.M.; O'Connor, K.E. Polyhydroxyalkanoate accumulating diversity of Pseudomonas species utilising aromatic hydrocarbons. Fems Microbiol. Lett. 2005, 253, 111-118. [CrossRef] [PubMed]

55. Valentino, F.; Karabegouic, L.; Majone, M.; Morgan-Sagastume, F.; Werker, A. Polyhydroxyalkanoate (PHA) storage within a mixed-culture biomass with simultaneous growth as a function of accumulation substrate nitrogen and phosphorus levels. Water Res. 2015, 77, 49-63. [CrossRef] [PubMed]

56. Muhr, A.; Rechberger, E.M.; Salerno, A.; Reiterer, A.; Malli, K.; Strohmeier, K.; Schober, S.; Mittelbach, M.; Koller, M. Novel description of mcl-PHA biosynthesis by Pseudomonas chlororaphis from animal-derived waste. J. Biotechnol. 2013, 165, 45-51. [CrossRef] [PubMed]

57. Gumel, A.M.; Annuar, M.S.M.; Heidelberg, T. Growth kinetics, effect of carbon substrate in biosynthesis of mcl-PHA by Pseudomonas putida Bet001. Braz. J. Microbiol. 2014, 45, 427-438. [CrossRef]

58. Schlegel, H.G.; Kaltwasser, H.; Gottschalk, G. A submersion method for culture of hydrogen-oxidizing bacteria: growth physiological studies. Arch. Mikrobiol. 1961, 38, 209-222. [CrossRef]

59. Brandl, H.; Gross, R.A.; Lenz, R.W.; Fuller, R.C. Pseudomonas oleovorans as a source of poly(beta-hydroxyalkanoates) for potential applications as biodegradable polyesters. Appl. Environ. Microb. 1988, 54, 1977-1982.

60. Lageveen, R.G.; Huisman, G.W.; Preusting, H.; Ketelaar, P.; Eggink, G.; Witholt, B. Formation of polyesters by Pseudomonas oleovorans-Effect of substrates on formation and composition of poly-(R)-3-hydroxyalkanoates and poly-(R)-3-hydroxyalkenoates. Appl. Environ. Microb. 1988, 54, 2924-2932.

61. Scheiner, D. Determination of ammonia and Kjeldahl nitrogen by indophenol method. Water Res. 1976, 10, 31-36. [CrossRef] 
62. Elbahloul, Y.; Steinbuhel, A. Large-scale production of poly(3-hydroxyoctanoic acid) by Pseudomonas putida GPo1 and a simplified downstream process. Appl. Environ. Microb. 2009, 75, 643-651. [CrossRef]

63. Kenny, S.T.; Runic, J.N.; Kaminsky, W.; Woods, T.; Babu, R.P.; Keely, C.M.; Blau, W.; O'Connor, K.E. Up-Cycling of PET (Polyethylene Terephthalate) to the Biodegradable Plastic PHA (Polyhydroxyalkanoate). Environ. Sci. Technol. 2008, 42, 7696-7701. [CrossRef] 